\section{ekf}

VYSOKÁ ŠKOLA BÁŇSKÁ EKONOMICKÁ FAKULTA

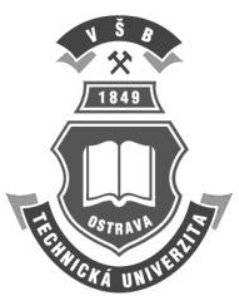

\title{
Statistical analysis of consumer sensory evaluation of selected varieties of white wine
}

\author{
Jan BORÁK ${ }^{\mathrm{a}^{*}}$, Zuzana NOVOTNÁ ${ }^{\mathrm{b}}$, Kateřina KOVÁŘOVÁa
}

${ }^{a}$ Department of Trade and Accounting Economics, Faculty of Economics and Management, Czech University of Life Sciences Prague, Kamýcká 129, 16521 Praha 6, Czech Republic.

${ }^{\mathrm{b}}$ Department of Statistics, Faculty of Economics and Management, Czech University of Life Sciences Prague, Kamýcká 129, 16521 Praha 6, Czech Republic.

\begin{abstract}
This paper evaluates the preferences of domestic consumers in the purchase and consumption of selected varieties of wine: Chardonnay, Sauvignon and Pinot Gris. Consumers are influenced by the information provided by their own personal experience, studies, the media or friends. An important factor in consumer choice is also the label and the bottle of the wine itself. A pilot survey showed that consumer preferences change from their first impression of a product based on their personal experience of the product, i.e. after tasting. This may be an important factor influencing the consumer's preferences when selecting varieties of wine. The results can be used, for example, by grape wine retailers in their marketing mix.
\end{abstract}

\section{Keywords}

Analysis, consumer preferences, sensory evaluation, wine.

JEL Classification: M300, M310

\footnotetext{
*borak@czu.cz (corresponding author)

The paper was supported by internal grants, Vyhodnocení preferencí českých spotřebitelů při nákupu révového vína No. 20131052 and Metody a techniky výzkumného projektu se zaměřením na různé formy No. 20131022, from the Internal Grant Agency of the Faculty of Economics and Management of the Czech University of Life Sciences in Prague.
} 


\title{
Statistická analýza smyslového hodnocení spotřebitelů vybraných odrůd bílého vína
}

\author{
Jan BORÁK, Zuzana NOVOTNÁ, Kateřina KOVÁŘOVÁ
}

\section{1. Úvod}

Révové víno a hrozny se staly součástí zdravé výživy člověka od nejstarších dob, jsou symbolem lidského žití. Historie vinohradnictví a vinařství $\mathrm{v}$ českých zemích se datuje od 1. století našeho letopočtu a je velice bohatá. $\mathrm{V}$ současné době patří vinařství k základním charakteristikám některých regionů České republiky, i když toto odvětví není celoplošně rozšiřřeno (Tomšík a kol., 2007).

Obliba vína v ČR stoupá na úkor ostatních alkoholických nápojů. Ačkoliv si Česká republika dlouhodobě drží první prríčku ve spotřebě piva na osobu, tak se v posledních letech rovněž začíná projevovat zvýšený zájem o víno. Spotřebitelé jsou již schopni rozeznat a ocenit kvalitní sortiment a postupně upouštějí od nákupu levnějších vín $\mathrm{z}$ kategorie stolní a začínají se stále častěji orientovat na kvalitnější nabídku jakostních a takzvaných zemských vín (Šperková a Duda, 2009).

At' už roste trh s vínem regionálně, národně či mezinárodně - zažívá, dá se říci, obrovský rozmach. Škála typů spotřebitelů vína se rozrůstá jak o ty, kteří mohou být považováni za znalce produktu, tak o ty, kteří konzumují víno bez ohledu na kvalitu (Gosch, 2005).

Spotřeba vína byla v roce $1990 \mathrm{v}$ ČR průměrně kolem 15 litrů vína na osobu ročně, nyní se pohybuje kolem 20 litrů. I tak ale ČR zaostává za Evropou. V zemích EU je průměr 32 litrů. Růst spotřeby v ČR je patrný, trend růstu spotřeby za posledních pět let je okolo $9 \%$ a předpokládá se, že by měla spotřeba $\mathrm{v}$ př́šstích letech růst stejným tempem (Economia, 2012). Roční výrobní objem vína v ČR je kolem 500000 až 600000 hektolitrů, který ale pokrývá domácí spotřebu jen asi z $25 \%$. Zbytek spotřeby je pokryt zahraniční produkcí, která činní 1588 tis. hektolitrů (Zajícová, 2012).

V České republice se používá pro zatřid’ování vína především germánský systém, který je založený na chemické analýze, která jej provádí na základě naměřeného obsahu cukru, tzv. obsahu cukernatosti. Mezi nejkvalitnější vína patří jakostní vína s př́vlastkem. Hrozny na výrobu musí splňovat všechny požadavky výroby, musí pocházet $\mathrm{z}$ jedné vinařské podoblasti a původ hroznů, jejich cukernatost, hmotnost, popř. odrůda nebo směs odrůd musí být ověřena SZPI a nesmí se u nich dodatečně zvyšovat cukernatost moštu.

Každé víno má svoji vlastní charakteristickou vlastnost a př́padné nedostatky se tak dají zjistit pouze ochutnávkou. Na toto testování je třeba chutová a čichová pamět', která pomáhá porovnávat vína stejných typů. Při testování jakosti se používají bodová ohodnocení, aby bylo možnost výsledky lépe porovnat a zpracovat.

Dle Krause a kol. (2010) se na víně hodnotí vzhled, vůně, chut' a celkový dojem. U vzhledu se posuzuje čirost a čistota, víno musí být naprosto bez zákalu. Jemné i silnější zákaly již ukazují na různé vady nebo nedostatky vína. Může se ukázat slabá opalescence u vína sudového, které není dostatečně vyškoleno, ta však jakost vína nemění. Vůně je jedním z nejdůležitějších znaků při hodnocení jakosti vína. Tvoří ji celá řada těkavých látek, a proto je důležité posuzovat víno při takové teplotě, aby se aromatické látky uvolňovaly za stejných podmínek. Vůně jakostních vín musí odpovídat odrůdovému charakteru nebo danému typu známkových vín. Nečistá vůně s náznakem vůně octa naznačuje začátek octovatění vína nebo jiného bakteriálního kvašení vína.

Samotná chut' tvoří celkový komplex látek, jehož jednotlivé složky jsou vnímány receptory chuti umístěnými na různých částech jazyka. Proto je nutno využít chutnání vín celého jazyka. Chut' vína musí být čistá, bez vedlejších příchutí a harmonická. Pokud tyto složky, jako je alkohol, kyseliny, popř́padě i trrísloviny, jednotlivě př́lišs vynikají, jedná se o víno neharmonické a nejakostní. U starších vín, která již mají vrchol svého vývoje za sebou, se může jednat o vína odumírající nebo v rozkladu. Po objektivním posouzení vlivu jednotlivých složek vína je nutno zhodnotit celkový charakter vína - celkový dojem, jenž je dán jejich kombinací a vzájemným působením a ukazuje na skutečnou jakost vín. Podle celkového dojmu se vína označují celou řadou speciálních výrazů, kterými je možno výstižně charakterizovat i nejjemnější odstíny jejich jakosti a vína jimi oslovovat (Kraus a kol., 2010).

$\mathrm{Na}$ trhu s vínem je dostupné nepřeberné množství odrůd tichého vína. To, jaké odrůdy tichých vín jsou spotřebiteli nejoblíbenější, je závislé právě na spotře- 
bitelských preferencích, které se mohou neustále měnit.

Spotřebitelé jsou ovlivněni informacemi a osobními zkušenostmi ze svého života, ze studia, ze sdělovacích prostředků či od známých. Významným faktorem výběru spotřebitele je etiketa a také samotná láhev vína. Etiketa je nutná součást každé láhve $s$ vínem a měly by na ni být uvedeny všechny podstatné informace pro spotřebitele, jako je odrůda a země původu vína, jaký je obsah alkoholu či cukru ve vínu či další informace. Kolem etikety bohužel panuje mnoho nepř́ijemných spekulací s uváděním zavádějících skutečností, které zbytečně matou spotřebitele (Krška a kol., 2006).

Při výběru vína mají možnost vybrat si z nejrůznějších odrůd vín. Odrůda vína je důležitá př̌i výběru, jelikož každá odrůda má svoji specifickou chut' a barvu. Jedním z faktorů je individuální chut' spotřebitele, kdy každému spotřebiteli může chutnat úplně něco jiného než ostatním. U chuti hraje důležitou roli také zbytkový cukr, který zůstal ve víně a nebyl spotřebován kvasinkami při kvasném procesu. Pokud je zbytkový cukr v přívlastkových vínech, jedná se většinou o fruktózu, která vzniká fotosyntézou přímo $\mathrm{v}$ listech révy vinné. $U$ jakostních vín s přívlastkem je zvyšování cukernatosti moštů zakázáno. Zbytkový cukr ve víně se označuje $\mathrm{v}$ souladu s vinařským zákonem na etiketě, $v$ gramech na litr, určenou terminologií. U tichých vín se dělí vína podle Krause a kol., (2010) dle zbytkového cukru na vína suchá, polosuchá, polosladká a sladká.

Jaké preference mají domácí spotřebitelé ve vztahu $\mathrm{k}$ odrůdě a jestli by využili plně nabídku právě domácích vinařù, pokud by tady byla, to je potřeba ověřit přesnou identifikací faktorů ovlivňujících spotřební chování a spotřebitelských preferencí při nákupu a spotřebě vína.

V minulosti byla provedena řada studií o tom, jak spotřebitelé vína $\mathrm{v}$ obchodech nakupují a jaký je vliv vín na nákupní chování (Lockshin a Hall, 2003). Od roku 2004 je pouze několik specifických měření, kde víno působí jako klíčový element $\mathrm{v}$ analýze nákupního chování (Hollebeek a kol., 2007 a Lockshin a kol., 2006). Jiné prŕíspěvky (Casini a kol., 2008) hledaly rozdíly mezi větším či menším zapojením spotřebitelů, ale nic z toho není hlavním cílem studií, jako je tato.

Cílem práce je statistická analýza smyslového hodnocení spotřebitelů odrůd bílého vína, konkrétně celosvětově nejznámější odrůdy Chardonnay, Sauvignon a Rulandské šedé. Dílčím cílem je identifikace preferencí spotřebitelů před degustací - hodnocení vína dle tvaru láhve, etikety, odrůdy hroznů, jakosti vína a zbytkového cukru. Dalším dílčím cílem je identifikace preferencí spotřebitelů po degustaci - hodnocení vína dle barvy, čistoty, vůně, chuti a celkového dojmu.

$\mathrm{Z}$ dílčích cílů je dále možno vyvodit určitou marketingovou strategii, jejímž cílem bude efektivní alokace omezených finančních prostředků vinařství ke zvýšení prodeje a udržení si konkurenční výhody. $\mathrm{K}$ tomu, aby mohl být na trhu vinař úspěšný a zaujímal větší tržní podíl, by se měla jeho marketingová strategie soustředit prredevším na zákazníka a jeho smyslové preference.

V závěru práce jsou formulována doporučení pro prodejce a spotřebitele vína.

\section{Metodika práce}

Sběr dat proběhl formou řizené degustace 3 vybraných odrůd révového vína: Chardonnay (vinařství U Dvou lip, ročník 2011, pozdní sběr, polosladké), Sauvignon (vinařství Zaječí, ročník 2010, pozdní sběr, polosuché) a Rulandské šedé (vinařství Vad'ura, ročník 2012, jakostní víno, polosuché). Jelikož se jednalo o pilotáž, byly pro šetření vybrány pouze 3 výše jmenované odrůdy. Degustace probíhala od záŕí do listopadu roku 2013 v Praze. Celkem se degustace zúčastnilo 120 osob, z toho 60 mužů a 60 žen. Všichni účastníci degustace byli dopředu seznámeni s ochutnávanými vzorky, protože nebylo cílem vyhodnotit nejlépe chutnající vzorek, nýbrž analyzovat smyslové hodnocení před ochutnáním vína a po ochutnání. Hodnocení dílčích kritérií i celkové hodnocení účastníci zaznamenávali na tzv. degustační list (př́loha 1).

Před samotnou degustací účastníci obodovali na desetibodové stupnici čtyři základní kritéria hodnocených vzorků, a to celkový vzhled láhve (tvar láhve a viněta), odrůdu vína, jakostní zařazení (přívlastek) a zbytkový cukr. Pro získání celkového hodnocení vybrané odrůdy před degustací byly tyto body základních kritérií sečteny. Tímto způsobem byly ohodnoceny před degustací všechny testované odrůdy.

Poté následovala samotná degustace. Účastníci nejdříve hodnotili barvu vína, poté jeho vůni, samotnou chut' a výsledný dojem po požití vína. Pro získání celkového hodnocení vybrané odrůdy po degustaci byly tyto body základních kritérií opět sečteny. Tímto způsobem byly ohodnoceny po degustací všechny testované odrůdy.

Následně po degustacích byla provedena průzkumová analýza dat, jejímž cílem je nalezení zvláštností statistického chování dat a ověrování jejich předpokladů pro následné statistické zpracování. Při statistickém vyhodnocení dat se předpokládá, že jde o závislé, stejně rozdělené náhodné veličiny pocházející z normálního rozdělení. Rozsah výběru postačuje $\mathrm{k}$ určení dostatečného odhadu parametrů polohy 
a variability či testování statistických hypotéz (Hebák, 2005).

Dále bylo použito ověrení normality výběru. Normalita výběru patř́ $\mathrm{k}$ základním předpokladům především z důvodu, že je založena na klasické analýze dat, testech nezávislosti prvků výběru a testování vybočujících měření. Testování normality bylo provedeno pomocí Shapirov-Wilkov testu (Hebák, 2005).

Testová statistika má tvar:

$$
\begin{gathered}
W=\frac{b^{2}}{S^{2}} \\
b=\sum_{i=1}^{k} a_{i}\left(e_{S(n-i+1)}-e_{S(i)}\right) \\
S^{2}=\sum_{i=1}^{n} e_{S i}^{2} .
\end{gathered}
$$

Pokud testová statistika vyjde takto:

$$
\begin{aligned}
& \mathrm{p}<\alpha \ldots \text { nelze zamítnout Ho na hladině } \alpha, \\
& \mathrm{p}>\alpha \ldots \text { lze zamítnout Ho na hladině } \alpha .
\end{aligned}
$$

Testy jsou vždy méně citlivé na odchylky od normality než diagnostické grafy. Pokud není normalita prokázána, je třeba hlouběji analyzovat data (Meloun a Militký, 2004).

Dále byl použit párový t-test, kdy každý prvek jednoho výběru tvoří pár $\mathrm{s}$ určitým prvkem druhého výběrového souboru.

Testovací kritérium:

$$
t=\frac{\bar{d}}{s_{d}} \sqrt{n}
$$

Byly zvoleny grafické metody histogramu a boxplotu ve statistickém programu Statistica 9 a SPSS 19. Pro komplexní interpretaci byly kombinovány početní i grafické metody (Kába, 1999).

Vztah mezi zvolenými proměnnými lze vyjádřit závislostí volnou, tedy tím, že změna jednoho jevu podmiňuje úroveň jiného jevu jen s určitou pravděpodobností.

\section{Výsledky a diskuse}

Celkové výsledky degustace jsou zaneseny do tabulky 1 . Je zde vidět, že největší sympatie před degustací vzorků získalo víno Chardonnay od vinařství U Dvou lip. Následuje Sauvignon od vinařství Zaječí a nejméně bodů získalo překvapivě Rulandské šedé od vinařství Vad'ura. Pořadí před degustací je nejvíce ovlivněno vzhledem láhve vína i samotnou vinětou. Účastníci většinou nevěděli, jak hodnotit př́ívlastky, což je připisováno spíše jejich neznalosti jakostního zařazení vín v České republice.

Po degustaci jednotlivých vzorků se pořadí na prvních dvou místech prohodilo, kdy Sauvignon sice získal nepatrný bodový nárůst o 0,09 bodu, nicméně Chardonnay ztratilo celé 2,00 body (pokles o 7,72 \%), tedy největší diferenci mezi porovnávanými vzorky. Body u rulandského šedého vzrostly o 0,50 (nárůst o 2,16 \%), což je největší bodový nárůst a můžeme jen spekulovat, jaké bodové hodnocení by dosáhlo, pokud by mělo vzhled láhve bodově ohodnocené jako zbývající dvě odrůdy.

Tabulka 1 Bodové hodnocení jednotlivých odrůd degustace

\begin{tabular}{|l|c|c|c|c|c|c|}
\hline & před & pořadí & po & pořadí & diference & $\begin{array}{c}\text { diference } \\
\%\end{array}$ \\
\hline Chardonna & 25,92 & 1. & 23,92 & 2. & $-2,00$ & $-7,72$ \\
\hline Sauvignon & 24,58 & 2. & 24,67 & 1. & 0,09 & 0,37 \\
\hline $\begin{array}{l}\text { Rulandské } \\
\text { šedé }\end{array}$ & 23,17 & 3. & 23,67 & 3. & 0,50 & 2,16 \\
\hline
\end{tabular}

Shapirův-Wilkův test se ve statistice použíá pro testování hypotézy, která říká, že náhodný výběr $x_{l}$, .... $x_{n}$ pochází $\mathrm{z}$ normálního rozložení s blíže nespecifikovanými parametry $\mu$ a $2, \mathrm{~N}(\mu, 2)$. Tento test je založen na zjištění, zda se body sestrojeného kvantilkvantilového grafu (Q-Q plotu) významně liší od regresní přímky proložené těmito body (Meloun a Militký, 2004).

Pomocí této testovací statistiky bylo zjištěno, že data před degustací splňují normální rozdělení $\mathrm{p}>\alpha$, neboli $0,95>0,05$ (i 0,01 ). Jak je vidět na obrázku 1 , tak normalita rozdělení byla prokázána.

Obrázek 1 Histogram dat před degustací

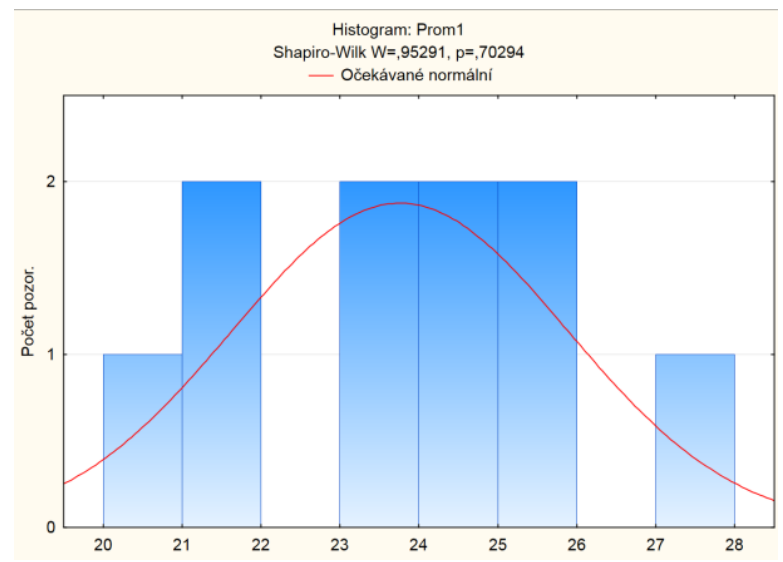

Zdroj: vlastní zpracování v programu Statistica 9

Jak nám ukazuje tato testovací statistiky, tak i data po degustaci z obrázku 2 splňují normální rozdělení $p>\alpha$ neboli $0,99>0,05$ (i 0,01$)$ a normalita rozdělení tedy byla prokázána.

V tomto článku byly použity charakteristiky polohy i variability. Aritmetický průměr se na základě proměnných liší. Před degustací má 23,78 bodů, po degustaci již 24,34 bodů. Dále v tabulce 2 popisných charakteristik lze nalézt variační koeficient, který 
vyjadřuje kolísavost hodnot. Nižší variační koeficient vyšel pro proměnné před degustací. Což je znakem vyrovnanějších hodnot pozorování. Vyšší variační koeficient vyšel pro proměnné po degustaci $(11,26 \%)$. Ukazatel šikmosti slouží $\mathrm{k}$ zjišstění míry symetrie (souměrnosti) rozdělení. Nejnižší hodnota ukazatele špičatosti vyšla u proměnných po degustaci. Což naznačuje, že proměnné po degustaci mají více normální rozdělení dat než proměnné před degustaci. Ukazatel špičatosti je založen na srovnání stupně nahuštěnosti hodnot prostřední velikosti se stupněm ostatních hodnot.

Obrázek 2 Histogram dat po degustaci

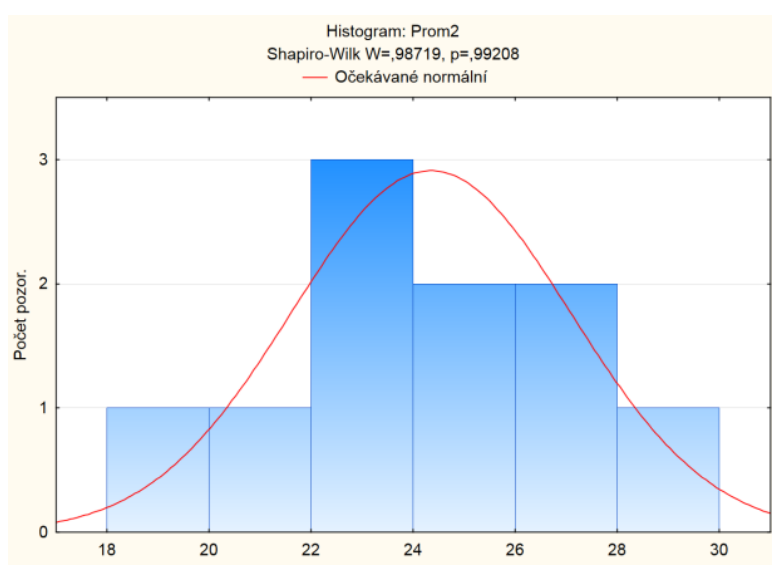

Zdroj: vlastní zpracování v programu Statistica 9

Tabulka 2 Popisné charakteristiky

\begin{tabular}{|l|c|c|c|c|c|c|c|c|}
\hline & $N$ & Prümé & Min & Max & $\begin{array}{l}\text { Směr. } \\
\text { odch. }\end{array}$ & $\begin{array}{c}\text { Var. } \\
\text { koef. }\end{array}$ & $\begin{array}{c}\text { Šik- } \\
\text { most }\end{array}$ & $\begin{array}{c}\text { Špi- } \\
\text { ćatost }\end{array}$ \\
\hline Prom1 & 10 & 23,76 & 20,90 & 27,30 & 2,13 & 8,95 & 0,11 & $-0,88$ \\
\hline Prom2 & 10 & 24,34 & 19,50 & 28,90 & 2,74 & 11,26 & $-0,02$ & 0,06 \\
\hline
\end{tabular}

Zdroj: vlastní zpracování v programu Statistica 9 a SPSS 19

Z obrázku 3 lze také vyčíst charakteristiky proměnných, kdy první menší boxplot (Proml) je pro proměnné před degustací a druhý větší je po degustaci (Prom2).

Pomocí párového t-testu bylo zjišt’ováno, zda existuje statisticky významný rozdíl v hodnocení 120 respondentů před degustací a po degustaci vín, viz tabulku 3.

Z výsledků testování, kde $\mathrm{p}>\alpha(0,48>0,05$ (i 0,01$)$ ), lze rozhodnout, že mezi hodnoceními je statisticky významný rozdíl. Rozhodnutí respondentů se před degustací liší od hodnocení po samotné degustaci na hladině významnosti 5,00 \% i 1,00\%.
Obrázek 3 Boxploty pro data před degustací (Prom1) a po degustaci (Prom2)

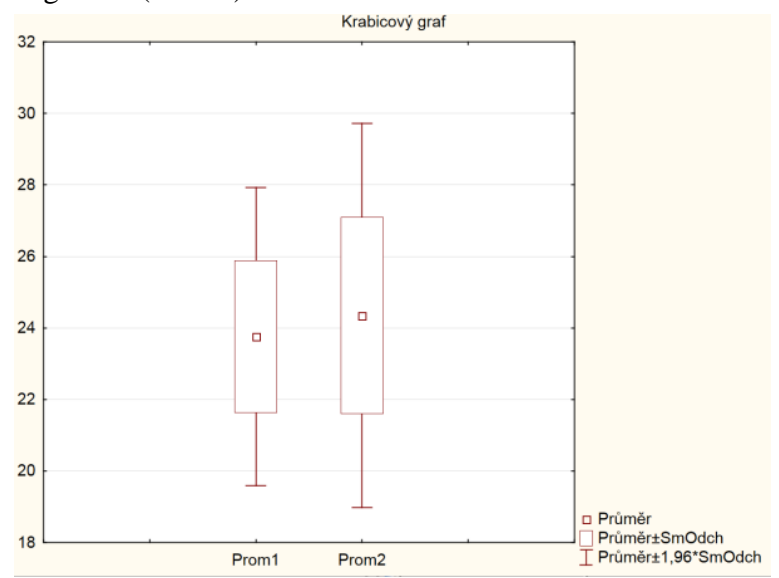

Zdroj: vlastní zpracování v programu Statistica 9 a SPSS 19

Tabulka 3 Párový t-test pro závislé soubory

\begin{tabular}{|c|c|c|c|c|c|c|c|c|}
\hline & $N$ & Rozdil & $\begin{array}{c}\text { Směr. } \\
\text { odch. } \\
\text { rozdilu }\end{array}$ & $t$ & $s v$ & $p$ & $\begin{array}{c}\text { Interval } \\
\text { spolehl. } \\
-95 \%\end{array}$ & $\begin{array}{c}\text { Interval } \\
\text { spolehl. } \\
+95 \%\end{array}$ \\
\hline Prom1 & & & & & & & \\
\hline Prom2 & 10 & $-0,59$ & 2,49 & $-0,74$ & 9 & 0,48 & $-2,36$ & 1,19 \\
\hline
\end{tabular}

Zdroj: vlastní zpracování v programu Statistica 9 a SPSS 19

\section{Závěr}

Provedené šetření na vybraných třech odrůdách bílého révového vína mělo za cíl statisticky analyzovat smyslové hodnocení spotřebitelů těchto vín a porovnat, jaké jsou preference spotřebitelů při nákupu před ochutnáním a po ochutnání dané odrůdy vína.

Při nákupu druhů uvedených $\mathrm{v}$ šetření se spotřebitel rozhoduje pro nákup vína na základě vyhodnocení tvaru láhve, etikety, odrůdy hroznů, jakosti vína a zbytkového cukru. Tyto aspekty jsou významné zejména $\mathrm{v}$ př́padě, kdy daný druh či produkt $\mathrm{z}$ konkrétního vinařství kupuje spotřebitel prvně.

Po ochutnání vína vzniká již senzorický dojem, který ovlivní další nákupní chování vůči tomuto produktu. Po degustaci bylo tudíž hodnoceno víno dle barvy, čistoty, vůně, chuti a celkového dojmu.

Závěry z šetření mohou být významné například pro prodejce a jejich prezentaci vín spotřebitelům či další marketingové aktivity.

Vzhledem $\mathrm{k}$ tomu, že rozhodnutí respondentů se před degustací liší od hodnocení po samotné degustaci, je pro prodejce vína lepší dělat ochutnávky, zejména u kvalitních a dražších vín či s horší graficky zpracovanou etiketou, protože při koupi po degustaci lidé rozhodují na základě jiných aspektů než prvního dojmu z láhve a viněty. 
Spotřebitel by měl při preferenci vína ke spotřebě brát $\mathrm{v}$ potaz více kritérií, než je jenom barva vína, odrůda a vinařská oblast. Není možné říci, že jedna odrůda je lepší nebo horší než druhá. Spotřebitel by měl také porovnat, jak bylo víno zatříděno a jaký zbytkový cukr víno obsahuje. Tyto informace a zkušenosti s tím související většinou spotřebitel nezískává komplexním způsobem a může u něj docházet k dezinformaci, která následně ovlivní jeho nákupní chování. Nejlepší doporučením pro spotřebitele je návštěva některé formy degustace, kde bude mít možnost porovnat mezi sebou více odrůd, různé hodnocení jakosti i vína se odlišným zbytkovým cukrem.

Tento pilotní projekt je podkladem pro komplexní šetření, kde bude porovnáváno více vzorků.

\section{Literatura}

CASINI, L., CAVICHI, A., CORSI, A. M. (2008). Trends in the British wine market and consumer confusion. British Food Journal 110(6): 545-558. http://dx.doi.org/10.1108/00070700810877870

GOSCH, F. (2005). Vinařský marketing. Valtice: Národní salon vín.

HEBÁK, P. a kol. (2005a). Vícerozměrné statistické metody 1. Praha: Informatorium.

HEBÁK, P. a kol. (2005b). Vicerozměrné statistické metody 2. Praha: Informatorium.

HOLLEBEEK, L.D., JAEGER, S.R., BRODIE, R.J., BALEMI, A. (2007). The influence of involvement on purchase intention for new world wine. Food Quality and Preference 18(8): 1033-1049.

http://dx.doi.org/10.1016/j.foodqual.2007.04.007

KÁBA, B. (1999). Statistické aspekty analýzy rozsáhlých datových souborů. Praha: ČZU v Praze.

KRAUS, V., HUBÁČEK, V., ACKERMANN, P. (2010). Rukovět' vinaře. Praha: Brázda.
LOCKSHIN, L., HALL, J. (2003). Consumer purchasing behaviour for wine: what we know and where we are going. In: Proceedings of the International Wine Marketing Colloquium. Adelaide: University of South Australia, 1-21.

LOCKSHIN, L., JARVIS, W., D'HAUTEVILLE, F., PERROUTY, J. (2006). Using simulations from discrete choice experiments to measure consumer sensitivity to brand, region, price, and awards in wine choice. Food Quality and Preference 17(3-4): 166178. http://dx.doi.org/10.1016/j.foodqual.2005.03.009

MELOUN, M., MILITKÝ, J. (2004). Statistická analýza experimentálních dat. Praha: Academia.

ŠPERKOVÁ, R., DUDA, J. (2009). Úvodní analýza situace v odvětví vinařství v ČR od roku 1989. Acta Universitatis agriculturae et silviculturae Mendelianae Brunensis 57(6): 287-296.

http://dx.doi.org/10.11118/actaun200957060287

TOMŠÍK, P., SEDLO, J., ŠPERKOVÁ, R. (2007). Management vinařstvi a lidé, stavby, príroda. Brno: VUT.

ZAJÍCOVÁ, P. (2012). Situační a výhledová zpráva Réva vinná a víno. Praha: MZe Č̌̆.

\section{Další zdroje}

ECONOMIA (2012). Nejvíce vína se loni vypilo v USA. [Online], cit. 23. 2. 2014. Dostupné z www: $<$ http://mam.ihned.cz/c1-55041150-nejvice-vina-seloni-vypilo-v-usa>.

KRŠKA, P., PU゚ČEK, M., SEDLO, J. (2006). Perspektivy vývoje a návrhy opatření politiky vinohradnictví a vinařství a rozvoje venkova v jihomoravském regionu. [Online], cit. 5. 3. 2014. Dostupné z www: <www.pefka.mendelu.cz/predmety/simul/koncepce.pd f>. 
Př́loha 1 Degustační list

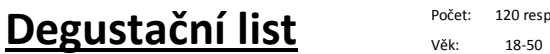

\begin{tabular}{|c|c|c|c|c|c|c|c|c|c|c|c|c|c|c|c|c|}
\hline & \multicolumn{5}{|c|}{ Obecné informace o vzorku } & \multicolumn{4}{|c|}{$\begin{array}{l}\text { bodové hodnocení } \\
\text { prèed degustaci varku }\end{array}$} & \multirow{2}{*}{$\begin{array}{c}\text { celkové } \\
\text { hodnoceni } \\
\text { PŔED } \\
\text { degustaci }\end{array}$} & \multicolumn{4}{|c|}{$\begin{array}{l}\text { bodové hodnoceni } \\
\text { po degustaci vzorku }\end{array}$} & \multirow{2}{*}{$\begin{array}{c}\text { celkové } \\
\text { hodnoceni } \\
\text { PO } \\
\text { degustaci }\end{array}$} & \multirow{2}{*}{ poznámk } \\
\hline & odrưda & vinarststi & ročnik & privilastek & cukr & $\begin{array}{l}\text { láhev } \\
\text { vinêta }\end{array}$ & odrúda & porivlastek & cukr & & barva & vũnĕ & chut' & dojem & & \\
\hline 1 & & & & & & & & & & & & & & & & \\
\hline 2 & & & & & & & & & & & & & & & & \\
\hline 3 & & & & & & & & & & & & & & & & \\
\hline 4 & & & & & & & & & & & & & & & & \\
\hline 5 & & & & & & & & & & & & & & & & \\
\hline 6 & & & & & & & & & & & & & & & & \\
\hline 7 & & & & & & & & & & & & & & & & \\
\hline 8 & & & & & & & & & & & & & & & & \\
\hline 9 & & & & & & & & & & & & & & & & \\
\hline 10 & & & & & & & & & & & & & & & & \\
\hline
\end{tabular}

Doporučené bodové hodnoceni: $0 \mathrm{~min}, 10 \mathrm{max}$ Přivlastek: zem-zemské, jak-jakostni, ps-pozdni sběr, vzh-výběr z hroznů, vzb-výběr z bobuli, led-ledové Cukr: su-suché, psu-polosuché, psl-polosladké, sl-sladké 
